\title{
Role of Prostaglandin E2 in Cirrhotic Patients with Spontaneous Bacterial Peritonitis
}

\author{
Ahmed Ibraheem Aboghiaty ${ }^{1}$, Ihab Barsoum Fahim ${ }^{1}$, Hanan Samir Ahmed ${ }^{2}$, Ahmed Fathy Gomaa ${ }^{1}$ \\ Departments of ${ }^{1}$ Internal Medicine and ${ }^{2}$ Clinical Pathology, Faculty of Medicine, Zagazig University, Egypt \\ *Corresponding author: Ahmed Ibraheem Aboghiaty, Mobile: (+2)01003567334, Email: dr.bogha@gmail.com
}

\begin{abstract}
Background: Spontaneous bacterial peritonitis (SBP) is the most frequent bacterial infection in patients who suffer from liver cirrhosis and ascites. Prostaglandin E2 (PGDE2) is considered a simple and accurate tool for diagnosing systemic inflammation and has a relevant impact on prognosis in cirrhotic patients.

Objective: We tried to detect the role of PGDE2 in serum and ascitic fluid as a diagnostic marker for eradication of SBP.

Patients and methods: This clinical-based prospective cohort study involved patients with liver cirrhosis, ascites and spontaneous bacterial peritonitis referred to the Internal Medicine Department, Faculty of Medicine, Zagazig University during the period from June 2020 to March2021. Patients with ascites were divided equally into: (a) case group included cirrhotic patients with SBP); and (b) control group included cirrhotic patients without SBP. All patients were subjected to complete clinical and laboratory examination. Serum and ascitic PGDE2 were estimated before and after five days of treatment.

Results: There was statistically significant difference between the studied groups regarding Child score and presence of HCC. Serum and ascitic PGDE2 was elevated in all cirrhotic groups; both of case and control had more than normal. However, PGDE2 level was lower in case group before treatment in comparison with control group, and after treatment PGDE2 levels was elevated.

Conclusion: Serum and ascitic fluid PGDE2 can be used as a diagnostic marker for SBP diagnosis and eradication. Serum PGDE2 is preferred due to its less invasiveness and minimal risk of complications.
\end{abstract}

Keywords: Liver Cirrhosis, PGDE2, SBP.

\section{INTRODUCTION}

Spontaneous bacterial peritonitis (SBP) is the most frequent bacterial infection in patients who suffer from liver cirrhosis and ascites ${ }^{(\mathbf{1})}$.

Patients at greatest risk for spontaneous bacterial peritonitis have decreased hepatic synthetic function with associated low total protein level or prolonged prothrombin time (PT) $(\geq 45 \%)^{(2)}$.

With respect to compromised host defenses, patients with severe acute or chronic liver disease are often deficient in complement and may also have malfunctioning of the neutrophils and reticuloendothelial systems ${ }^{(3)}$. In cirrhosis with portal hypertension, the microcirculation in the intestinal mucosa is disturbed, resulting in a reduction of mucosal blood flow that leads to congestion, edema, ischemia, and potentially to erosions, intestinal bacterial overgrowth and impaired mucosal integrity ${ }^{(4)}$.

PGD E2 is promoted by IL-6, a proinflammatory IL upregulated in advanced liver disease ${ }^{(5)}$. Its value reflects the degree of systemic inflammation, regardless of the underlying cause. Patients with decompensated cirrhosis. PGDE2 as a surrogate marker of systemic inflammatory response and PGDE2 levels were higher in patients who developed systemic inflammatory response syndrome, infection, and alcoholic hepatitis (6). In cirrhosis, several factors independent of infection, such as hepatocellular carcinoma (HCC), necrosis or the ongoing local inflammatory reaction in liver tissue and bacterial translocation (BT), are potentially able to induce the synthesis of these markers ${ }^{(7)}$.

Therefore, the aim of the present study was to detect the role of Prostaglandin E2 (PGDE2) in serum and ascitic fluid as a diagnostic marker for eradication of SBP.

\section{PATIENTS AND METHODS}

This clinical-based prospective cohort study involved 52 patients with liver cirrhosis and ascites referred to the Internal Medicine Department, Faculty of Medicine, Zagazig University during the period from June 2020 to March 2021. Patients with ascites were divided equally into: (a) case group included cirrhotic patients with SBP and (b) control group included cirrhotic patients without SBP.

Inclusion criteria: Cirrhotic patients with ascites and diagnosed as SBP of both genders

Exclusion criteria: Patient with Collagen vascular disorders, patient with any form of acute arthritis, patient with acute infections and septicemia and patient with other causes of elevated PGDE2.

\section{Methodology:}

Liver cirrhosis diagnosis done by clinical signs, laboratory and ultrasound findings and severity of the liver disease was scored according to Child-Pugh's classification; Child-Pugh A=5-6 points, Child-Pugh $\mathrm{B}=7-9$ points, Child-Pugh $\mathrm{C}=10$ or more points. 
All patients were subjected to a thorough history, complete clinical examination and routine investigations including liver function tests: serum bilirubin (total and direct), serum albumin, serum ALT and AST measured by kinetic method; Renal function tests: serum creatinine, urea; Coagulation profile: PT, PTT and INR.

Ultrasonography for diagnosis of cirrhosis as a shrunken liver (small and nodular), enlarged spleen (splenomegaly) and portal hypertension (dilated portal vein, hilar varices), ascites, hepatocellular carcinoma (HCC).

\section{Special Investigations:}

PGDE2 measurement in serum and ascitic fluid and ascites polymorphonuclear leukocytes (PMNs) measurement. The PGDE2 ELISA is based on the principle of a solid phase enzyme-linked immunosorbent assay. The assay system utilizes a unique monoclonal antibody directed against a distinct antigenic determinant on the PGDE2 molecule.

\section{Ethical approval:}

The study was approved by the Ethical Committee of Zagazig Faculty of Medicine. An informed consent was obtained from all patients in this research. Every patient received an explanation for the purpose of the study. All given data were used for the current medical research only. This work has been carried out in accordance with The Code of Ethics of the World Medical Association
(Declaration of Helsinki) for studies involving humans.

\section{Follow up:}

After 5 days from starting treatment of SBP by ceftriaxone $2 \mathrm{~g} / 24 \mathrm{~h}$ or cefotaxime $2 \mathrm{~g} / 8 \mathrm{~h} ; 3 \mathrm{~cm}$ blood was taken for measuring serum PGDE2. $5 \mathrm{~cm}$ ascitic fluid sample was taken by paracentesis with all aseptic precautions for measuring PMN and ascitic fluid PGDE2.

\section{Statistical analysis}

All data were analyzed using SPSS 20.0 for windows (SPSS Inc., Chicago, IL, USA) and MedCalc 13 for windows (MedCalc Software Bvba, Ostend, Belgium). Quantitative data were expressed as the mean \pm standard deviation (SD) and median (range), and qualitative data were expressed as absolute frequencies (number) and relative frequencies (percentage). Independent and paired Student t-test, Mann-Whitney U test, and Wilcoxon signed rank test were used for quantitative data, while Chi-square test or Fisher's exact test were used for qualitative data. $\mathrm{P}$ value $\leq 0.05$ was considered significant.

\section{RESULTS}

The present study showed a statistically nonsignificant difference between the studied groups regarding age, gender, smoking, and presence of comorbid diabetes or hypertension (Table 1).

Table (1) Comparison between the studied groups regarding demographic data

\begin{tabular}{|c|c|c|c|}
\hline \multirow[b]{2}{*}{ Parameter } & Case group & Control group & \multirow[t]{2}{*}{$\mathbf{p}$} \\
\hline & $\mathrm{N}=26(\%)$ & $\mathrm{N}=26(\%)$ & \\
\hline $\begin{array}{l}\text { Age (year): } \\
\text { Mean } \pm \text { SD } \\
\text { Min - Max }\end{array}$ & $\begin{array}{c}61.04 \pm 9.55 \\
46-87\end{array}$ & $\begin{array}{c}60 \pm 13.34 \\
25-77\end{array}$ & 0.748 \\
\hline $\begin{array}{l}\text { Gender: } \\
\text { Female } \\
\text { Male }\end{array}$ & $\begin{array}{l}11(42.3) \\
15(57.7)\end{array}$ & $\begin{array}{l}10(36.4) \\
16(63.6)\end{array}$ & 0.569 \\
\hline $\begin{array}{l}\text { Smoking: } \\
\text { No } \\
\text { Yes }\end{array}$ & $\begin{array}{l}13(50) \\
13(50)\end{array}$ & $\begin{array}{l}14(53.8) \\
12(46.2)\end{array}$ & 0.781 \\
\hline $\begin{array}{l}\text { Diabetes: } \\
\text { No } \\
\text { Yes }\end{array}$ & $\begin{array}{c}20(76.9) \\
6(23.1)\end{array}$ & $\begin{array}{c}17(65.4) \\
9(34.6)\end{array}$ & 0.358 \\
\hline $\begin{array}{l}\text { Hypertension: } \\
\text { No } \\
\text { Yes }\end{array}$ & $\begin{array}{c}21(80.8) \\
5(19.2)\end{array}$ & $\begin{array}{c}19(73.1) \\
7(26.9)\end{array}$ & 0.51 \\
\hline
\end{tabular}

SD: Standard deviation

There was statistically significant difference between the studied groups regarding Child score and presence of HCC. There was statistically non-significant difference between the studied groups regarding grades of ascites (Table 2). 
Table (2) Comparison between the studied groups regarding present history

\begin{tabular}{|l|c|c|c|}
\hline Parameter & Case group & Control group & \multirow{2}{*}{$\mathbf{p}$} \\
\cline { 2 - 3 } & $\mathbf{N = 2 6 ( \% )}$ & $\mathbf{N = 2 6}(\%)$ & \\
\hline Ascites: & $8(30.8)$ & $9(34.6)$ & \\
Moderate & $18(69.2)$ & $17(65.4)$ & 0.788 \\
Tense & $13(50)$ & $21(80.8)$ & \multirow{2}{*}{$0.02^{*}$} \\
\hline Hepatocellular carcinoma (HCC): & $13(50)$ & $5(19.2)$ & \\
Absent & $3(11.5)$ & $11(42.3)$ & \multirow{2}{*}{$0.012^{*}$} \\
Present & $23(88.5)$ & $15(57.7)$ & \\
\hline Child score: & \multicolumn{2}{|l}{} \\
B & \multicolumn{2}{|l}{} \\
C & \multicolumn{2}{|l|}{} \\
\hline
\end{tabular}

*: Significant difference

Within case group, there was statistically significant decrease in prothrombin time and serum bilirubin and creatinine level after treatment. Also, there was statistically non-significant increase in serum albumin after treatment (Table 3).

Table (3) Changes in liver, kidney function test and bleeding profile among case group before and after treatment

\begin{tabular}{|l|c|c|c|}
\hline \multicolumn{1}{|c|}{ Parameter } & Before treatment & After treatment & \multirow{2}{*}{ p } \\
\cline { 2 - 3 } & Mean \pm SD & Mean \pm SD & \\
\hline Albumin $(\mathrm{g} / \mathrm{dL})$ & $2.43 \pm 0.46$ & $2.48 \pm 0.41$ & 0.211 \\
\hline PT $(\mathrm{sec})$ & $18.54 \pm 4.76$ & $17.43 \pm 3.55$ & $0.002^{*}$ \\
\hline Bilirubin $(\mathrm{mg} / \mathrm{dL})$ & $6.31 \pm 1.79$ & $4.34 \pm 0.31$ & $<0.001^{* *}$ \\
\hline Serum creatinine $(\mathrm{mg} / \mathrm{dl})$ & $2.05 \pm 0.54$ & $1.64 \pm 0.09$ & $0.022^{*}$ \\
\hline
\end{tabular}

$*$ : Significant difference, $* *$ : Highly significant difference

Serum and ascitic PGDE2 was elevated in all cirrhotic groups both of case and control had more than normal. However, PGDE2 level was lower in case group before treatment in comparison with control group (Table 4).

Table (4) Comparison between the studied groups regarding serum and ascitic PGDE2 before treatment

\begin{tabular}{|l|c|c|c|}
\hline \multirow{2}{*}{ Parameter } & Case group & Control group & \multirow{2}{*}{ p } \\
\cline { 2 - 3 } & Median & Median & \\
\hline Ascites PGDE2 $(\mathrm{g} / \mathrm{dL})$ & 605.38 & 790.65 & $0.009^{*}$ \\
\hline Serum PGDE2 $(\mathrm{g} / \mathrm{dL})$ & 608.25 & 1477.37 & $0.001^{* *}$ \\
\hline
\end{tabular}

*: Significant difference, **: Highly significant difference

There was statistically significant change in serum, ascitic fluid PGDE2 and PMN after treatment (Figure 1).

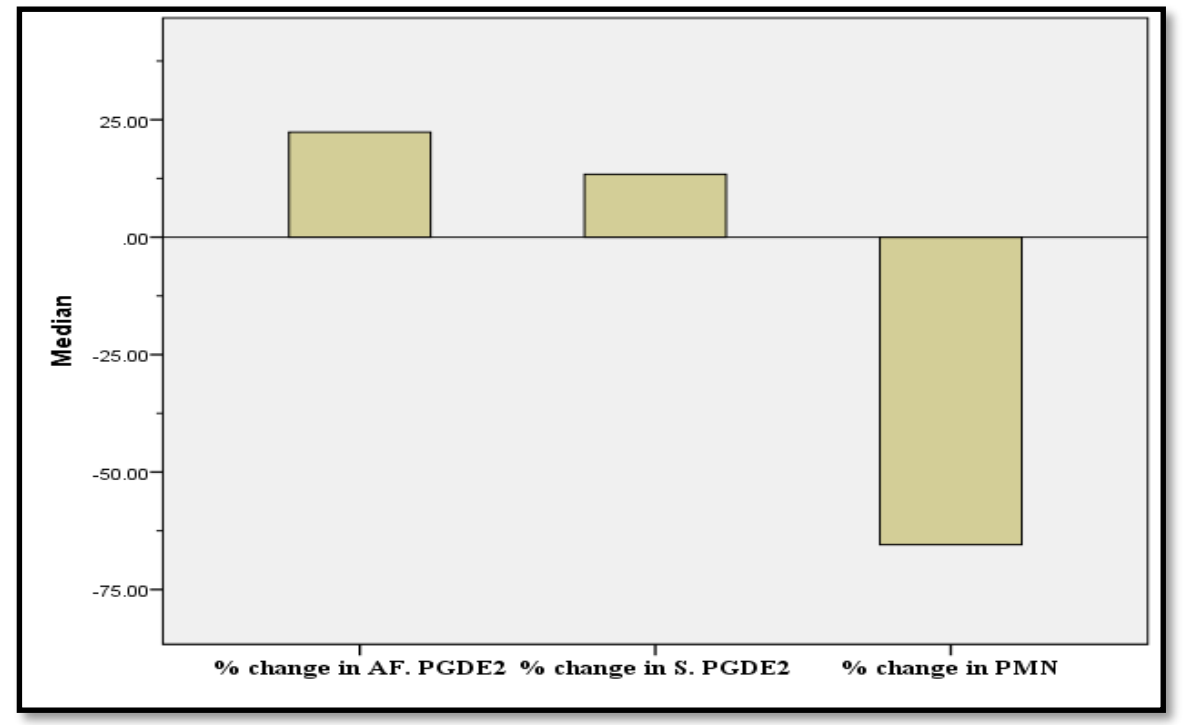

Figure (1): Simple bar chart showing percent change in serum, ascitic fluid PGDE2 and ascitic fluid PMN after therapy among case group

There was non-significant relation between mortality and ascitic fluid and serum PGDE2 before and after treatment among case group (Table 5). 
Table (5) Relation between serum, ascitic fluid PGDE2 and mortality among the studied patients

\begin{tabular}{|c|c|c|c|c|}
\hline \multirow{3}{*}{ Parameter } & Ascites fluid & \multirow[t]{2}{*}{$\mathbf{p}$} & Serum & \multirow[t]{2}{*}{$\mathbf{p}$} \\
\hline & Median (range) & & Median (range) & \\
\hline & \multicolumn{4}{|c|}{ Before treatment } \\
\hline \multirow[t]{2}{*}{$\begin{array}{l}\text { Mortality: } \\
\text { No } \\
\text { Yes }\end{array}$} & $\begin{array}{l}574.94(4.55-1541.92) \\
1078.57(73.96-1541.92)\end{array}$ & 0.123 & $\begin{array}{l}762.96(38.12-2178.94) \\
370.47(34.15-706.79)\end{array}$ & 0.394 \\
\hline & \multicolumn{4}{|c|}{ er treatment } \\
\hline $\begin{array}{l}\text { Mortality: } \\
\text { No } \\
\text { Yes }\end{array}$ & $\begin{array}{l}853.44(02.28-1760) \\
1145.35(1086.15-1204.56)\end{array}$ & 0.185 & $\begin{array}{l}697.68(390.02-1092.18) \\
860.69(719.19-1002.15)\end{array}$ & 0.258 \\
\hline
\end{tabular}

\section{DISCUSSION}

Spontaneous bacterial peritonitis (SBP) is the most common infection in patients with cirrhosis ${ }^{(8)}$. Prostaglandin E2 (PGDE2), a principal mediator of inflammation, which is a lipid mediator derived from arachidonic acid and is generated through an enzymatic cascade controlled by cyclooxygenase enzymes at sites of inflammation and infection ${ }^{(9)}$. Also, Rizk et al. ${ }^{(10)}$ concluded that serum PGDE2 correlates well with the PMN count and protein levels in ascitic fluid and reliably diagnoses.

This prospective study included 52 cirrhotic patients with ascites divided into: case group of cirrhotic patients with SBP and control group of cirrhotic patients without SBP. The aim of this study was to establish the role of PGDE2 in serum and ascitic fluid as marker for diagnosis and detection of SBP.

Patients suffered from liver cirrhosis with different comorbidities, 6 patients were diabetic $(23.1 \%)$ in case group and 9 patients $(34.6 \%)$ in control group, 5 patients were hypertensive $(19.2 \%)$ in case group and 7 patients (27.9\%) were in control group, 13 patients were smokers $(50 \%)$ in case group and 12 patients $(46.2 \%)$ were in control group. This results were in agreement with Luo et al. ${ }^{(\mathbf{1 1})}$ who reported that the median onset age and gender between 2 groups were not significantly different. Nearly $70 \%$ of patients suffered from cirrhosis with SBP were males. Also, Mehta et $\boldsymbol{a l} .{ }^{(12)}$ reported that the adjusted risk of decompensated cirrhosis was higher in diabetic compared with nondiabetic patients.

As regard Child score and presence of HCC there was statistically significant difference between the studied groups, this came in agreement with study of Mellinger et al. ${ }^{(13)}$ who showed that higher MELD score and the development of hepatic encephalopathy are the independent predictor for in-hospital mortality in patients with decompensated cirrhosis.

Variceal hemorrhage predisposes to SBP and randomised trials have shown reduction in infection and mortality when antibiotics are administered upon admission, now it is a standard of care in all patients with cirrhosis and gastrointestinal bleeding whether or not ascites is present ${ }^{(\mathbf{1 4})}$.

Serum and ascitic PGDE2 was elevated in all cirrhotic groups both of case and control had more than normal. However, PGDE2 level was lower in case group before treatment in comparison with control group, and after treatment PGDE2 levels was elevated, which came in agreement with Luo et al. ${ }^{(11)}$ who studied role of ascitic PGDE2 in diagnosis of spontaneous bacterial peritonitis and prediction of inhospital mortality in patients with decompensated cirrhosis where they found a statistically significant increase in the mean serum and ascitic fluid PGDE2 level after antibiotic therapy.

Our study showed non-significant relation between mortality and ascitic fluid and serum PGDE2 before and after treatment among case group. These results agree with Luo et al. (11) who studied 224 patients enrolled in their study, there were 15 (7.0\%) cases of death during hospitalization. Previous published studies showed that higher MELD score and the development of hepatic encephalopathy are the independent predictor for in-hospital mortality in patients with decompensated cirrhosis ${ }^{(13,15)}$. So our study is corresponding with the previous studies.

\section{CONCLUSION}

Serum and ascitic fluid PGDE2 can be used as a diagnostic marker for SBP diagnosis and eradication. Serum PGDE2 is preferred due to its less invasiveness and minimal risk of complications.

\section{Financial support and sponsorship: Nil. Conflict of interest: Nil.}

\section{REFERENCES}

1. Lata J, Stiburek O, Kopacova M (2009): Spontaneous bacterial peritonitis: a severe complication of liver cirrhosis. World Journal of Gastroenterology, 15(44): 5505-8.

2. Ghassemi S, Garcia-Tsao G (2007): Prevention and treatment of infections in patients with cirrhosis. Best Practice \& Research Clinical Gastroenterology, 21(1): 77-93.

3. Alaniz C, Regal R (2009): Spontaneous bacterial peritonitis: a review of treatment options. Pharmacy and Therapeutics, 34(4): 204-9.

4. Wiest $R$ (2011): Bacterial translocation and alterations of the digestive system. In Chronic Liver Failure: Humana Press. Pp. 189-218.

5. Bota $D$, van Nuffelen M, Zakariah A et al. (2005): Serum level of C-reactive protein and procalcitonin 
in critically ill patients with cirrhosis of the liver. $\mathbf{J}$ Lab CLin Med., 146:347-351.

6. Cervoni J, Thevenot T, Weil D et al.(2012): C-reactive protein predicts short-term mortality in patients with cirrhosis. J Hepatol., 6:1299-1304.

7. Pieria G, Agarwalb B, Andrew K et al. (2014): Creactive protein and bacterial infection in cirrhosis. An Gastroenterol., 27(2): 113-120.

8. Alexopoulou A, Danai A, Larisa E (2017): Bacterial translocation markers in liver cirrhosis. Annals of Gastroenterology, 30: 486-497

9. Chizzolini R, Chicheportiche M, Alvarez C et al. (2008): Prostaglandin E2 synergistically with interleukin-23 favors human Th17 expansion. Blood, 112 (9): 3696-3703.

10. Rizk E, Elzehery R, Zakaria S (2014): Ascitic fluid calprotectin and serum C-reactive protein as diagnostic markers for spontaneous bacterial peritonitis. Afro-Egypt J Infect Endem Dis., 4(3): 117-125.
11. Luo J, Wu X, Zhang Y et al. (2019): Role of ascitic prostaglandin E2 in diagnosis of spontaneous bacterial peritonitis and prediction of in-hospital mortality in patients with decompensated cirrhosis. Medicine (Baltimore), 98(26): 16016-21.

12. Mehta S, Brancati F, Strathdee S et al. (2003): Hepatitis $\mathrm{C}$ virus infection and incident type 2 diabetes. Hepatology, 38:50-56.

13. Mellinger J, Richardson C, Mathur A (2015): Variation among United States hospitals in inpatient mortality for cirrhosis. Clin Gastroenterol Hepatol., 13: 577-84.

14. Dever J, Sheikh M (2015): Spontaneous bacterial peritonitis-bacteriology, diagnosis, treatment, risk factors and prevention. Alimentary Pharmacology \& Therapeutics, 41(11): 1116-1131.

15. Nobre S, Cabral J, Gomes J (2008): In-hospital mortality in spontaneous bacterial peritonitis: a new predictive model. Eur J Gastroenterol Hepatol., 20:117681. 